\title{
Slope position regulates response of carbon and nitrogen stocks to cattle grazing on rough fescue grassland
}

\author{
Bin Zhang ${ }^{1,2} \cdot$ Ben W. Thomas $^{3} \cdot$ Ryan Beck $^{2} \cdot$ Walter D. Willms ${ }^{2} \cdot$ Mengli Zhao $^{1} \cdot$ Xiying Hao $^{2}$
}

Received: 15 January 2018 / Accepted: 31 March 2018 / Published online: 16 April 2018

(C) The Author(s) 2018

\begin{abstract}
Purpose Grasslands play a crucial role in offsetting greenhouse gas emissions and mitigating climate change. A moderate change in grassland carbon $(\mathrm{C})$ and nitrogen $(\mathrm{N})$ stocks may substantially alter the global $\mathrm{C}$ and $\mathrm{N}$ cycle and thereby influence climate. But how grassland $\mathrm{C}$ and $\mathrm{N}$ stocks respond to grazing and slope position remains uncertain. This research investigates how $\mathrm{C}$ and $\mathrm{N}$ stocks respond to cattle grazing along a landscape slope.

Materials and methods We studied a grassland that has been grazed by cattle at four cattle stocking rates $(0,1.2,2.4$, and 4.8 animal unit months (AUM) ha ${ }^{-1}$ ) since 1949, representing control (CK), light (L), heavy (H), and very heavy (VH) grazing intensities, respectively. Samples were taken from the top and bottom slope positions within each paddock (only the top position in $\mathrm{CK}$ ); $\mathrm{C}$ and $\mathrm{N}$ stocks in soil, roots, litter, and standing crop were estimated. Soil $\mathrm{C}$ and $\mathrm{N}$ stocks were estimated based on equivalent mass $\left(1500 \mathrm{Mg} \mathrm{ha}^{-1}\right)$. Root $\mathrm{C}$ and $\mathrm{N}$ stocks were estimated to the depth of $15 \mathrm{~cm}$.

Results and discussion All parameters, except for litter N stock and standing crop C stock, significantly responded to the interaction of grazing intensity and slope position. In the bottom position, soil and standing crop $\mathrm{C}$ and $\mathrm{N}$ stocks as well as litter $\mathrm{C}$ stock were higher with the $\mathrm{L}$ treatment than with $\mathrm{VH}$, while no significant differences were found among the three grazed treatments for root $\mathrm{C}$ and litter $\mathrm{N}$ stocks. In the top position, soil and root $\mathrm{C}$ and $\mathrm{N}$ stocks were higher with the $\mathrm{VH}$ treatment than with $\mathrm{L}$, whereas litter $\mathrm{C}$ and $\mathrm{N}$ stocks and standing crop $\mathrm{C}$ stock were lower with $\mathrm{VH}$ than with $\mathrm{L}$.

Conclusions Our results provide evidence that slope position plays an important role in regulating the response of $\mathrm{C}$ and $\mathrm{N}$ stocks to grazing and may need to be considered when developing optimal grazing management strategies.
\end{abstract}

Keywords Carbon and nitrogen stocks $\cdot$ Cattle grazing $\cdot$ Fescue grassland $\cdot$ Slope position

Responsible editor: Zucong Cai

Electronic supplementary material The online version of this article (https://doi.org/10.1007/s11368-018-1992-5) contains supplementary material, which is available to authorized users.

Xiying Hao

xiying.hao@agr.gc.ca

1 College of Grassland, Resources and Environment, Inner Mongolia Agricultural University, Hohhot 010011, China

2 Agriculture and Agri-Food Canada, Lethbridge Research and Development Centre, 5403-1st Ave. S, Lethbridge, AB T1J 4B1, Canada

3 Agriculture and Agri-Food Canada, Agassiz Research and Development Centre, 6947 Highway 7, Post Office Box 1000, Agassiz, BC V0M 1A0, Canada

\section{Introduction}

Grasslands play a crucial role in sequestering $\mathrm{C}$ due to their vast geographic distribution around the world (Conant et al. 2001) and high potential to absorb $\mathrm{C}$ from the atmosphere (Lal 2004). It has been estimated that grasslands account for $20 \%$ of the total global $\mathrm{C}$ in both soil and vegetation (Adams et al. 1990) and the $C$ sequestration rate in grassland soils is perhaps as much as $0.5 \mathrm{Pg} \mathrm{C}_{\text {year }}{ }^{-1}$ (Scurlock and Hall 1998). This indicates that even a moderate change in grassland $\mathrm{C}$ and $\mathrm{N}$ stocks may substantially alter the global $\mathrm{C}$ and $\mathrm{N}$ cycle. Therefore, there is a need to understand how grassland $\mathrm{C}$ and $\mathrm{N}$ stocks change with human disturbances.

Grazing exerts significant influences on multiple $\mathrm{C}$ and $\mathrm{N}$ pools in grassland ecosystems. For example, herbivory can directly affect the growth, survival, and fitness of most plants, 
which may depress or in some instances promote aboveground biomass and litter production (Naeth et al. 1991; Ferraro and Oesterheld 2002; Wang et al. 2017). Furthermore, this process could also affect the biomass allocation between above and belowground, while indirectly affecting root $\mathrm{C}$ and $\mathrm{N}$ exudation (Mikola et al. 2009; Wilson et al. 2018). On the other hand, the hoof action of livestock may influence $\mathrm{C}$ and $\mathrm{N}$ storage through its effects on litter decomposition rate and soil physical status (Semmartin et al. 2008). Soil is the main reservoir of $\mathrm{C}$ and $\mathrm{N}$ in grassland ecosystems, and previous studies have shown that livestock grazing alters the accumulation and release of soil $\mathrm{C}$ and N (Tanentzap and Coomes 2012; Gao et al. 2018). However, the direction and magnitude of grazing effects are highly contextdependent and regulated by the complex interactions among grazing strategy, climate, and soil (McSherry and Ritchie 2013). Therefore, no general conclusions have been broadly applicable related to grassland $\mathrm{C}$ and $\mathrm{N}$ storage in response to livestock grazing.

Studies have suggested that slope should be incorporated into grazing experiments since it could affect the availability and movement of water and nutrients (Gerrard 1981; Mwendera and Saleem 1997). More importantly, slope could also affect the distribution of herbivores (Ganskopp and Vavra 1987) through its effects on plant growth and species composition. But how slope position mediates $\mathrm{C}$ and $\mathrm{N}$ stock responses to livestock grazing is still uncertain.

Prior to cultivation, the natural grassland of Canada covered approximately 61.5 M ha (Clayton et al. 1977), mostly distributed in the southwest Canadian Prairie. However, with European settlement beginning in the late 1800s and the development of modern agriculture, about $50 \mathrm{M}$ ha of natural grassland is now used for crop production or urban expansion (Statistics Canada 1991-2011). Most of the remaining grassland is used for grazing. Previous studies have shown that grazed Canadian grasslands function as a net $\mathrm{C}$ sink under appropriate management (Wang et al. 2014). A better understanding of the effects of livestock grazing on grassland $\mathrm{C}$ and $\mathrm{N}$ stocks is essential to the development of win-win grazing strategies, which benefit both human interests and the environment. The main purpose of this study was to investigate the response of different $\mathrm{C}$ and $\mathrm{N}$ stocks (soil, root, litter, and standing crop) to long-term cattle grazing and determine how slope position regulates the response of those parameters.

\section{Materials and methods}

\subsection{Study site and grazing treatment}

Fieldwork was conducted at the Agriculture and AgriFood Canada (AAFC) Range Research Substation near Stavely, Alberta $\left(50^{\circ} 12^{\prime} \mathrm{N}, 113^{\circ} 54^{\prime} \mathrm{W}\right)$. The topography is undulating, varying in elevation from 1280 to $1420 \mathrm{~m}$ above sea level. The climate is sub-humid, with mean annual precipitation and temperature (1997-2013) of $494 \mathrm{~mm}$ and $5.3{ }^{\circ} \mathrm{C}$, respectively. The dominant soil type is Orthic Black Chernozem with a clay loam to loam texture. Vegetation is primarily composed of foothills rough fescue (Festuca campestris Rydb) with codominant Parry's oat grass (Danthonia parryi Scribn) and Kentucky bluegrass (Poa pratensis L.).

Three cattle stocking rates, 1.2, 2.4, and 4.8 animal unit months (AUM) ha ${ }^{-1}$, were established in 1949 to represent light $(\mathrm{L})$, heavy $(\mathrm{H})$, and very heavy $(\mathrm{VH})$ grazing intensities, respectively. One non-grazed exclosure (CK) was also included in this study. Wroe et al. (1988) recommended the optimal grazing rate for this grassland should be $1.6 \mathrm{AUM} \mathrm{ha}^{-1}$. The grazing period was from late May to mid-November. The experimental area was never fertilized, nor was the vegetation ever cut. The basic design of the grazing experiment is outlined in earlier work (Willms et al. 1985; Dormaar and Willms 1998).

\subsection{Field sampling and lab analysis}

At the end of July 2016, 50-m transects were laid perpendicular to the slope at the bottom and top slope positions within each paddock. Only one transect was selected in the top slope position for the ungrazed control due to the nature of the slope in this treatment (Fig. S1, Electronic Supplementary Material). Within each transect, we established ten evenly-spaced sampling points that were treated as ten replications. We established one quadrat $(0.5 \mathrm{~m} \times 0.5 \mathrm{~m})$ at each sampling point and clipped all the standing crop. Subsequently, all the surface litter was collected. Dry matter of standing crop and litter was obtained by oven-drying samples at $65^{\circ} \mathrm{C}$ for $48 \mathrm{~h}$ and then all the samples were finely ground for determination of $\mathrm{C}$ and $\mathrm{N}$ concentration. Within each sampling point near the quadrats, four soil cores (diameter $=6.5 \mathrm{~cm}, \approx 1 \mathrm{~m}$ apart) were collected (15-cm depth). Three of them were combined and air-dried and then finely ground for estimating soil $\mathrm{C}$ and $\mathrm{N}$ stocks. Soil bulk density was determined based on stone-free soil mass. For the fourth soil core, roots were extracted by washing away the soil in the lab; they were then oven-dried, weighed, and finely ground before determining their $\mathrm{C}$ and $\mathrm{N}$ concentrations using an automated CN Analyzer (NC2100, CE Instruments, Milan, Italy).

Concentrations of organic $\mathrm{C}$ and total $\mathrm{N}$ for standing crop, litter, and soil were determined with the finely ground samples as described for roots using an automated $\mathrm{CN}$ analyzer (NC2100, CE Instruments, Milan, Italy). Soil organic C was determined after acidification with $6 \mathrm{~mol} \mathrm{~L}^{-1} \mathrm{HCL}$, as described by Ellert and Rock (2008). 


\subsection{Data handling and statistical analysis}

The $\mathrm{C}$ and $\mathrm{N}$ stocks in standing crop and litter were calculated using biomass and $\mathrm{C}$ and $\mathrm{N}$ content. Root biomass and $\mathrm{N}$ content were estimated following the equations of Janzen et al. (2002) to exclude the influence of soil particles adhering to roots. The pure root fraction $(f)$ of the total sample (root and soil particles) was estimated with Eq. (1):

$f=(\mathrm{Ct}-\mathrm{Cs}) /(\mathrm{Cr}-\mathrm{Cs})$

where $\mathrm{Ct}, \mathrm{Cs}$, and $\mathrm{Cr}$ represent the $\mathrm{C}$ concentrations of the total sample, soil, and pure root, respectively. Here, we assumed the pure root $\mathrm{C}$ concentration was $48 \%$. Pure root $\mathrm{N}$ concentration $(\mathrm{Nr})$ was calculated by Eq. (2):

$\mathrm{Nr}=(\mathrm{Cr}-\mathrm{Cs}) /(\mathrm{Ct}-\mathrm{Cs}) \times(\mathrm{Nt}-\mathrm{Ns})+\mathrm{Ns}$

where $\mathrm{Nt}$ and $\mathrm{Ns}$ represent the total $\mathrm{N}$ concentration in the total sample and soil, respectively.

The soil $\mathrm{C}$ and $\mathrm{N}$ stocks were calculated based on equivalent mass per hectare (Ellert and Bettany 1995). Grazing can increase soil bulk density (Li et al. 2012; Thomas et al. 2018), which will increase the total mass of soil in the surface layer, hence distorting a comparison among treatments. Here, we used an equivalent mass of $1500 \mathrm{Mg} \mathrm{ha}^{-1}$. Soil C and $\mathrm{N}$ stocks in the surface layer $(0-15 \mathrm{~cm})$ were calculated using the measured organic $\mathrm{C}$ and $\mathrm{N}$ concentrations; deep layer $(>15 \mathrm{~cm}) \mathrm{C}$ and $\mathrm{N}$ stocks were calculated using the data from Li et al. (2012) which were mostly from the top slope position. We assume that there is no difference in deep layer soil C and $\mathrm{N}$ contents between the top and bottom positions.

The treatments were unreplicated, and we made the assumption that the subsampling error was representative of the experimental error. Since there is only a top position for the control, data were analyzed in two steps. In the first step, a two-way ANOVA was conducted among three grazing treatments without control to assess the effect of grazing intensity, slope position, and their interactions. The results are shown in Table 1. For the second step, we combined the grazing intensity and slope position for a total of seven treatments (CK-top, L-top, L-bottom, H-top, H-bottom, VH-top, and VH-bottom) and used a one-way ANOVA to estimate their differences. In Figs. 1 and 2, we contrasted the three grazing treatments in the bottom position and four grazing treatments in the top position, separately.

The ANOVA analysis was conducted using PROC MIXED in SAS (SAS Institute Inc 2008); various types of covariance structures (e.g., UN, AR (1), and CS) were fitted and the one with the lowest AIC value was selected for the final analysis. Normality and homoscedasticity were tested on the residuals. The LSD test was used for all mean comparisons and significant grazing intensity or slope position effects are reported at $p<0.05$.

\section{Results}

The results reveal that the equivalent mass of soil $\mathrm{C}$ stock was affected by grazing $(p=0.019)$ and the interaction of grazing and slope position $(p<0.001$, Table 1$)$. Soil $\mathrm{C}$ stock in the $\mathrm{L}$ treatment was higher in the bottom position than that in the top position (Fig. 1) while the soil $\mathrm{C}$ stocks of the $\mathrm{H}$ and $\mathrm{VH}$ treatments were greater in the top position. Soil $\mathrm{C}$ stock with the $\mathrm{L}$ treatment was also significantly higher than that with $\mathrm{H}$ and $\mathrm{VH}$ at the bottom of the slope, but lower at the top (Fig. 1). Root $\mathrm{C}$ stock responded to slope position and its interaction with grazing intensity ( $p=0.008$ and $<0.001$, respectively). At the bottom slope position, no differences were found among the three grazing intensities for root $\mathrm{C}$ stock; however, at the top position, root $\mathrm{C}$ stock was lower $(p<0.05)$ with the $\mathrm{L}$ treatment than that in $\mathrm{H}$ and $\mathrm{VH}$, but no difference was found between $\mathrm{L}$ and $\mathrm{CK}$ (Fig. 1). Litter $\mathrm{C}$ stock was affected by grazing $(p<0.001)$, slope position $(p=0.001)$, and their interactions $(p=0.004)$. Litter $\mathrm{C}$ stock with $\mathrm{L}$ treatment was only higher than $\mathrm{VH}$ treatment at the bottom position and no significant differences were found between $\mathrm{L}$ and $\mathrm{H}$ treatments. At the top position, in contrast, litter $\mathrm{C}$ stock decreased with increasing grazing intensity from $\mathrm{CK}$ to $\mathrm{VH}$ treatment. Standing crop C stock decreased significantly with the VH treatment in both top and bottom positions, and on average varied from $2.27 \mathrm{Mg} \mathrm{C} \mathrm{ha}^{-1}$ with $\mathrm{H}$ treatment to $1.63 \mathrm{Mg} \mathrm{C} \mathrm{ha}^{-1}$ with VH stocking rates.

The equivalent mass soil $\mathrm{N}$ stock was affected by slope position and the interaction of grazing intensity and slope position ( $p=0.008$ and $<0.001$, respectively). Soil N stock
Table 1 ANOVA results of the effect of cattle stocking rate (SR) and slope position $(\mathrm{P})$ on soil, root, litter, and standing crop carbon $(\mathrm{C})$ and nitrogen $(\mathrm{N})$ stocks

\begin{tabular}{|c|c|c|c|c|c|c|c|c|}
\hline & \multicolumn{2}{|l|}{ Soil } & \multicolumn{2}{|l|}{ Root } & \multicolumn{2}{|l|}{ Litter } & \multicolumn{2}{|c|}{ Standing crop } \\
\hline & C stock & $\mathrm{N}$ stock & C stock & $\mathrm{N}$ stock & C stock & $\mathrm{N}$ stock & C stock & $\mathrm{N}$ stock \\
\hline & \multicolumn{8}{|c|}{ Probability levels } \\
\hline SR & 0.019 & 0.228 & 0.179 & 0.004 & $<0.001$ & 0.001 & $<0.001$ & 0.605 \\
\hline$P$ & 0.763 & 0.008 & 0.007 & $<0.001$ & 0.001 & 0.001 & 0.022 & 0.019 \\
\hline $\mathrm{SR} * \mathrm{P}$ & $<0.001$ & $<0.001$ & 0.049 & 0.021 & 0.004 & 0.068 & 0.474 & 0.026 \\
\hline
\end{tabular}


Fig. 1 Effects of cattle stocking rate and slope position on soil (1500 $\mathrm{Mg} \mathrm{ha}^{-1}$ soil mass), root $(0-15 \mathrm{~cm})$, litter, and standing crop carbon $(\mathrm{C})$ stocks in a rough fescue grassland. Different colors denote different grazing treatments $(\mathrm{L}$, light grazing intensity $\left(1.2 \mathrm{AUM} \mathrm{ha}^{-1}\right) ; \mathrm{H}$, heavy grazing intensity (2.4 AUM ha $\left.^{-1}\right)$; VH, very heavy grazing intensity (4.8 $\left.\mathrm{AUM} \mathrm{ha}^{-1}\right)$; CK, control, no grazing). For the same position, grazing treatments with different uppercase letters differ at $p<0.05$; for the same grazing treatment, slope positions with different lowercase letters differ at $p<0.05$

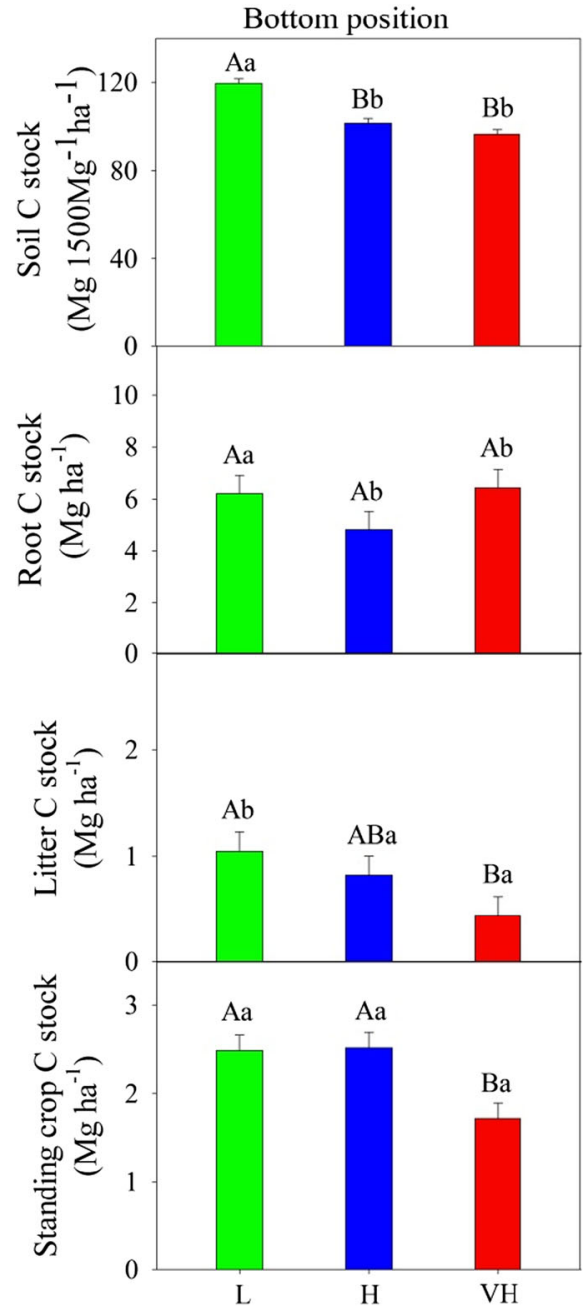

in the $\mathrm{L}$ treatment was higher in the bottom position than that in the top position (Fig. 2) but with the $\mathrm{H}$ and VH treatments was greater in the top position. Similar to soil C stock, the soil $\mathrm{N}$ stock in the $\mathrm{L}$ treatment was higher than that for $\mathrm{H}$ and $\mathrm{VH}$ in bottom position but lower in the top position. Root $\mathrm{N}$ stock responded to grazing intensity $(p=0.004)$, slope position ( $p=$ $0.003)$, and their interaction $(p=0.021)$. At the bottom slope position, the root $\mathrm{N}$ stock with the $\mathrm{H}$ treatment was significantly lower with $\mathrm{VH}$ but no difference was found between $\mathrm{L}$ and VH treatments; at the top position, root $\mathrm{N}$ stock with $\mathrm{VH}$ treatment was significantly higher than that with $\mathrm{CK}$ and $\mathrm{L}$ treatments. For litter $\mathrm{N}$ stock, our results show that there were no differences among the three grazed treatments in the bottom position, while in the top position, it decreased significantly with increased grazing intensity. On average, litter $\mathrm{N}$ stock varied from $90.51 \mathrm{~kg} \mathrm{ha}^{-1}$ in CK to $22.07 \mathrm{~kg} \mathrm{ha}^{-1}$ in the VH treatment. Standing crop N stock was affected by slope position $(p=0.019)$ and its interaction with grazing intensity $(p=0.026)$. In the bottom position, standing crop $\mathrm{N}$ stock in $\mathrm{L}$ was higher than that in VH while no differences were found among the three grazing intensities in the top position.

\section{Discussion}

As stated by Thomas et al. (2018), most long-term grazing studies lack replication and this limits our ability to make strong conclusions about grazed grassland landscapes in general. However, this data provides important information to help fill research gaps related to long-term grazing in the undulating landscape. Our results show that all parameters, except for litter $\mathrm{N}$ stock and standing crop $\mathrm{C}$ stock, significantly responded to the interaction of grazing intensity and slope position. This indicates that slope position may be important in regulating responses of $\mathrm{C}$ and $\mathrm{N}$ stocks to cattle grazing on this rough fescue grassland. The concept of catena was first used to describe the spatial variation of soil organic matter and nutrient supply along toposequences (Gerrard 1981) which suggests that the downhill movement of material due to the gravity and water movement results in a predictable sequence of soil characteristics from the top to bottom slope positions. Bottom positions frequently have larger resource pools than the top positions under natural or low disturbance conditions (Aguilar and Heil 1988; Burke et al. 1999), which is supported 
Fig. 2 Effects of cattle stocking rate and slope position on soil (1500 $\mathrm{Mg} \mathrm{ha}^{-1}$ soil mass), root $(0-15 \mathrm{~cm})$, litter, and standing crop nitrogen $(\mathrm{N})$ stocks in a rough fescue grassland. Different colors denote different grazing treatments (L, light grazing intensity $\left(1.2 \mathrm{AUM} \mathrm{ha}^{-1}\right) ; \mathrm{H}$, heavy grazing intensity (2.4 AUM ha $\left.{ }^{-1}\right)$; VH, very heavy grazing intensity (4.8 $\mathrm{AUM} \mathrm{ha}^{-1}$ ); CK, control, no grazing). For the same position, grazing treatments with different uppercase letters differ at $p<0.05$; for the same grazing treatment, slope positions with different lowercase letters differ at $p<0.05$
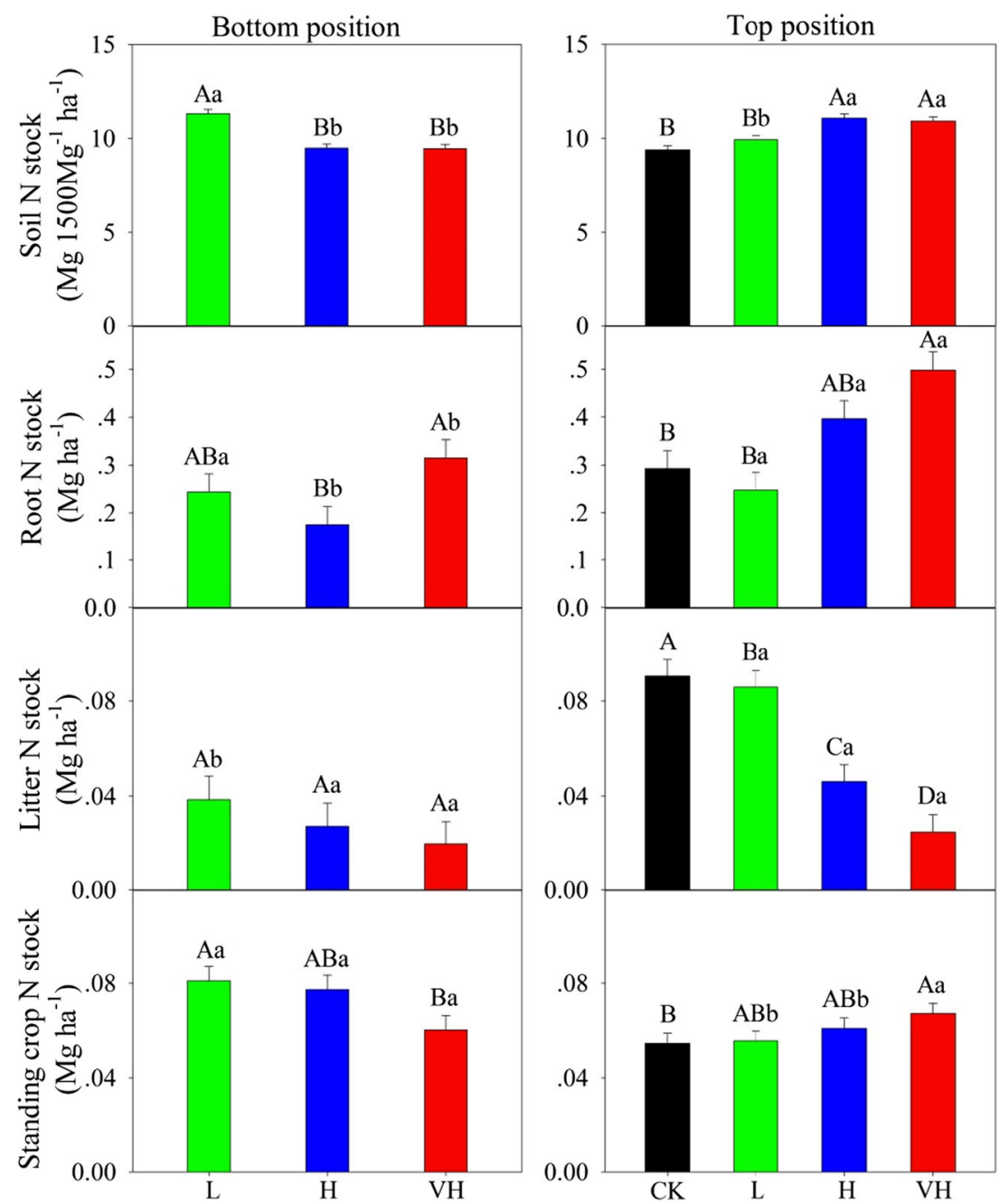

by our results showing that soil $\mathrm{C}$ and $\mathrm{N}$ stocks in the bottom slope position were higher than those in the top under the $\mathrm{L}$ treatment (Figs. 1 and 2).

In contrast to light grazing, heavy and very heavy grazing did not exhibit the development of a catena but rather the opposite effect where $\mathrm{C}$ and $\mathrm{N}$ were lost at the lower slope position. This is similar to the results from Sigua and Coleman (2010), who found that the top slope position had a higher soil organic $\mathrm{C}$ content than the bottom slope position under longterm cattle grazing. The reason for this is not clear but we speculate that it is the result of disproportionately heavier grazing pressure at the bottom slope position, which would have created conditions for reduced productivity and greater erosion potential. Better plant growth conditions in the bottom position may have led to more livestock activity compared to the top position, which has been observed in previous studies (Pinchak et al. 1991; Sigua and Coleman 2010). Therefore, grazing intensity in the bottom position may be greater than expected, while in the top position, it may not reach the same level of cattle grazing activity. This hypothesis is supported by previous research at this field site. For example, Willms
(1987) found that even though the lower slope position had $50 \%$ more forage production than the upper position, the topographic preference of the cattle was greatest in the lower slope position, so that forage utilization was greater in the lower than the upper slope position. Our recent research also found that labile and total soil organic $\mathrm{C}$ concentrations in the bottom position were lower than those in the top position (Zhang et al. 2018).

Our study demonstrated that high grazing intensity (2.4 and 4.8 AUM ha ${ }^{-1}$ ) decreased grassland $\mathrm{C}$ stocks in the bottom position. This is supported by the fact that in the bottom slope position, very heavy grazing induced a net decrease in $\mathrm{C}$ stocks of 22.93, 0.77, and $0.61 \mathrm{Mg} \mathrm{ha}^{-1}$, for soil (equivalent soil mass basis), standing crop, and litter, respectively, compared with light grazing. The results suggest that in the bottom position, over-grazing may reduce $\mathrm{C}$ sequestration capacity of this grassland. Decreased soil $\mathrm{C}$ stock may be partially explained by lower $\mathrm{C}$ inputs from litter and standing crop. However aboveground biomass contributes very little $\mathrm{C}$ to the soil; roots are the main source of soil C. Our results show that root $\mathrm{C}$ stock was not affected by grazing in the bottom 
position. The stability of root biomass may be responsible for the lack of response of root $\mathrm{C}$ stock since we assumed that pure root C content was constant (48\%) across the grazing intensities, which may be a valid assumption for grazed grasslands. Previous studies have found that grassland can maintain belowground production, which has been considered as an important mechanism enabling ecosystems to be resilient to grazing or other disturbances (Coughenour 1991; McNaughton et al. 1998). Together, our results suggest that grazing had little effect on soil $\mathrm{C}$ and $\mathrm{N}$ input in the bottom position, and other mechanisms are likely impacting soil $\mathrm{C}$ and $\mathrm{N}$. Increased $\mathrm{C}$ and $\mathrm{N}$ loss from soil may another reason for this phenomenon. Grazinginduced declines in vegetation cover may increase the proportion of bare ground which may increase the risk of $\mathrm{C}$ and $\mathrm{N}$ loss through wind and water erosion and leaching. Meanwhile, increased soil temperature arising from reduced vegetation cover (Yates et al. 2000) along with better water availability due to the downward movement of water from the top position may facilitate greater microbial activity and increased $\mathrm{CO}_{2}$ emissions from the $\mathrm{VH}$ treatment.

In contrast to the bottom position, we found that with $\mathrm{VH}$ treatment in the top position, there were higher soil and root $\mathrm{C}$ and $\mathrm{N}$ stocks. As mentioned above, we attributed the different responses between the two positions to the disproportionate grazing pressure. Cattle may prefer to graze more at the bottom than the top slope position, and thus create greater disturbance there. As a result, the VH treatment may experience a moderate grazing effect at the top slope position. This is in line with previous studies which found that moderate grazing could increase soil C sequestration (He et al. 2011). At the same time, grazing may facilitate the growth of plants with shallow roots (Ingram et al. 2008) and hence increase the surface layer root $\mathrm{C}$ and $\mathrm{N}$ stocks. With $\mathrm{VH}$ treatment, lower litter and standing crop $\mathrm{C}$ stocks may be related to the decrease of aboveground primary production ( $\mathrm{Li}$ et al. 2008; Gao et al. 2018) and a smaller mass of residual crop following grazing. Livestock dung and urine could increase the soil available N (Frank and Evans 1997) and hence increase plant N content (Mikola et al. 2009). In the current study, we also found that the standing crop $\mathrm{N}$ content was significantly higher with the VH treatment (data not shown here); increased standing crop $\mathrm{N}$ content may explain why the $\mathrm{VH}$ treatment led to lower standing crop mass but higher $\mathrm{N}$ stock.

\section{Conclusions}

Cattle grazing affected the mass of $\mathrm{C}$ and $\mathrm{N}$ stocks but their response to grazing is influenced by slope position. This is particularly evident for the bottom position where soil and standing crop $\mathrm{C}$ and $\mathrm{N}$ stocks, as well as litter $\mathrm{C}$ stock with light grazing are greater than those with very heavy grazing. Very heavy grazing produced greater soil and root $\mathrm{C}$ and $\mathrm{N}$ stocks in the top slope than those in the bottom but reduced litter $\mathrm{C}$ and $\mathrm{N}$ stocks and standing crop $\mathrm{C}$ stock compared to light grazing. We found no evidence that root $\mathrm{C}$ stock and litter $\mathrm{N}$ stock were affected by grazing. Our results suggest that slope position plays an important role in regulating the response of $\mathrm{C}$ and $\mathrm{N}$ stocks to grazing. Therefore, slope position should be considered when developing grazing management strategies.

Acknowledgements We gratefully acknowledge the two-year scholarship provided to the lead author by China Scholarship Council, Ministry of Education, P. R. China. This study was supported by Key Laboratory of Grassland Resources Ministry of Education People's Republic of China. Special thanks to Alberta Environment and Parks for permission to access the site for soil sampling.

Funding information This research was funded by Agriculture and AgriFood Canada Growing Forward 2 program (AAFC GF2 J-001349).

Open Access This article is distributed under the terms of the Creative Commons Attribution 4.0 International License (http:// creativecommons.org/licenses/by/4.0/), which permits unrestricted use, distribution, and reproduction in any medium, provided you give appropriate credit to the original author(s) and the source, provide a link to the Creative Commons license, and indicate if changes were made.

\section{References}

Adams JM, Faure H, Faure-Denard L, McGlade J, Woodward F (1990) Increases in terrestrial carbon storage from the Last Glacial Maximum to the present. Nature 348:711-714

Aguilar R, Heil R (1988) Soil organic carbon, nitrogen, and phosphorus quantities in northern Great Plains rangeland. Soil Sci Soc Am J 52: 1076-1081

Burke IC, Lauenroth WK, Riggle R, Brannen P, Madigan B, Beard S (1999) Spatial variability of soil properties in the shortgrass steppe: the relative importance of topography, grazing, microsite, and plant species in controlling spatial patterns. Ecosystems 2:422-438

Clayton JS, Ehrlich WA, Cann DB, Day JH, Marshall IB (1977) Soil of Canada, vol 1. Canada Department of Agriculture, Reseach Branch, Ottawa $243 \mathrm{pp}$

Conant RT, Paustian K, Elliott ET (2001) Grassland management and conversion into grassland: effects on soil carbon. Ecol Appl 11: 343-355

Coughenour MB (1991) Biomass and Nitrogen Responses to Grazing of Upland Steppe on Yellowstone's Northern Winter Range. J Appl Ecol 28:71-82

Dormaar JF, Willms WD (1998) Effect of forty-four years of grazing on fescue grassland soils. J Range Manag 51:122-126

Ellert B, Bettany J (1995) Calculation of organic matter and nutrients stored in soils under contrasting management regimes. Can J Soil Sci 75:529-538

Ellert BH, Rock L (2008) Stable isotopes in soil and environmental research. In: Carter MR, Gregorich EG (eds) Soil sampling and methods of analysis, 2nd edn. CRC Press, Boca Raton, pp 693-711

Ferraro DO, Oesterheld M (2002) Effect of defoliation on grass growth. A quantitative review. Oikos 98:125-133

Frank DA, Evans RD (1997) Effects of native grazers on grassland N cycling in Yellowstone National Park. Ecology 78:2238-2248 
Ganskopp D, Vavra M (1987) Slope use by cattle, feral horses, deer, and bighorn sheep. Northwest Sci 61:74-81

Gao X, Thomas BW, Beck R, Thompson DJ, Zhao M, Willms WD, Hao X (2018) Long-term grazing alters soil trace gas fluxes from grasslands in the Foothills of the Rocky Mountains, Canada. Land Degrad Dev 29:292-302

Gerrard AJ (1981) Soils and landforms. An integration of geomorphology and pedology. George Allen \& Unwin (Publishers) Ltd, London

He NP, Zhang YH, Yu Q, Chen QS, Pan QM, Zhang GM, Han XG (2011) Grazing intensity impacts soil carbon and nitrogen storage of continental steppe. Ecosphere 2:1-10

Ingram L, Stahl P, Schuman G, Buyer J, Vance G, Ganjegunte G, Welker J, Derner J (2008) Grazing impacts on soil carbon and microbial communities in a mixed-grass ecosystem. Soil Sci Soc Am J 72: 939-948

Janzen H, Entz T, Ellert B (2002) Correcting mathematically for soil adhering to root samples. Soil Biol Biochem 34:1965-1968

Lal R (2004) Soil carbon sequestration to mitigate climate change. Geoderma 123:1-22

Li CL, Hao X, Zhao ML, Han GD, Willms WD (2008) Influence of historic sheep grazing on vegetation and soil properties of a Desert Steppe in Inner Mongolia. Agr Ecosyst Environ 128:109-116

Li CL, Hao X, Ellert BH, Willms WD, Zhao ML, Han GD (2012) Changes in soil $\mathrm{C}, \mathrm{N}$, and $\mathrm{P}$ with long-term (58 years) cattle grazing on rough fescue grassland. J Plant Nutr Soil Sci 175:339-344

McNaughton S, Banyikwa F, McNaughton M (1998) Root biomass and productivity in a grazing ecosystem: the Serengeti. Ecology 79:587592

McSherry ME, Ritchie ME (2013) Effects of grazing on grassland soil carbon: a global review. Glob Chang Biol 19:1347-1357

Mikola J, Setälä H, Virkajärvi P, Saarijärvi K, Ilmarinen K, Voigt W, Vestberg M (2009) Defoliation and patchy nutrient return drive grazing effects on plant and soil properties in a dairy cow pasture. Ecol Monogr 79:221-244

Mwendera E, Saleem M (1997) Infiltration rates, surface runoff, and soil loss as influenced by grazing pressure in the Ethiopian highlands. Soil Use Manag 13:29-35

Naeth M, Bailey A, Pluth D, Chanasyk D, Hardin R (1991) Grazing impacts on litter and soil organic matter in mixed prairie and fescue grassland ecosystems of Alberta. J Range Manag 44:7-12

Pinchak WE, Smith MA, Hart RH, Waggoner JW Jr (1991) Beef cattle distribution patterns on foothill range. J Range Manag 44:267-275

SAS Institute Inc (2008) SAS OnlineDoc® 9. SAS Institute Inc., Cary
Scurlock J, Hall D (1998) The global carbon sink: a grassland perspective. Glob Chang Biol 4:229-233

Semmartin M, Garibaldi LA, Chaneton EJ (2008) Grazing history effects on above- and below-ground litter decomposition and nutrient cycling in two co-occurring grasses. Plant Soil 303:177-189

Sigua GC, Coleman SW (2010) Spatial distribution of soil carbon in pastures with cow-calf operation: effects of slope aspect and slope position. J Soils Sediments 10:240-247

Statistics Canada (1991-2011) Census of agriculture. Available at: http:// www.statcan.gc.ca/pub/95-629-x/4/4182522-eng.htm. Accessed 06 May 2017

Tanentzap AJ, Coomes DA (2012) Carbon storage in terrestrial ecosystems: do browsing and grazing herbivores matter? Biol Rev 87:7294

Thomas BW, Gao X, Zhao M, Bork EW, Hao X (2018) Grazing altered carbon exchange in a dry mixedgrass prairie as a function of soil texture. Can J Soil Sci 98:136-147

Wang X, VandenBygaart A, McConkey BC (2014) Land management history of Canadian grasslands and the impact on soil carbon storage. Rangel Ecol Manag 67:333-343

Wang Z, Han G, Hao X, Zhao M, Ding H, Li Z, Wang J, Hamilton A, Liu Y, Lata A (2017) Effect of manipulating animal stocking rate on the carbon storage capacity in a degraded desert steppe. Ecol Res 32: 1001-1009

Willms WD (1987) Forage production and utilization in various topographic zones of the fescue grasslands. Can J Anim Sci 68:211-223

Willms WD, Smoliak S, Dormaar JF (1985) Effects of stocking rate on a rough fescue grassland vegetation. J Range Manag 38:220-225

Wilson CH, Strickland MS, Hutchings JA, Bianchi TS, Flory SL (2018) Grazing enhances belowground carbon allocation, microbial biomass, and soil carbon in a subtropical grassland. Glob Chang Biol. https://doi.org/10.1111/gcb.14070

Wroe R, Smoliak S, Adams B, Wilms W, Anderson M (1988) Guide to range condition and stocking rates for Alberta grasslands, 1988. Alberta Forestry, Lands and Wildlife. Public Lands Division, Edmonton

Yates CJ, Norton DA, Hobbs RJ (2000) Grazing effects on plant cover, soil and microclimate in fragmented woodlands in south-western Australia: implications for restoration. Aust Ecol 25:36-47

Zhang B, Thomas BW, Beck R, Liu K, Zhao M, Hao X (2018) Labile soil organic matter in response to long-term cattle grazing on sloped rough fescue grassland in the foothills of the Rocky Mountains, Alberta. Geoderma 318:9-15 